\title{
Pawpaw Fruit Chilling Injury and Antioxidant Protection
}

\author{
Federica Galli \\ Former Graduate Student, Department of Horticulture, University of Kentucky, Lexington, KY \\ 40546-0091 \\ Douglas D. Archbold ${ }^{1}$ \\ Professor of Horticulture, Department of Horticulture, University of Kentucky, Lexington, KY \\ 40546-0091
}

\author{
Kirk W. Pomper \\ Principal Investigator of Horticulture and Curator, USDA National Clonal Germplasm Repository for \\ Asimina spp., Atwood Research Facility, Kentucky State University, Frankfort, KY 40601-2355
}

\begin{abstract}
AdDITIONAL INDEX wORDS. regular atmosphere storage, ethylene, respiration, glutathione, ascorbate, phenolics
Abstract. Pawpaw (Asimina triloba) fruit stored longer than 4 weeks at $4{ }^{\circ} \mathrm{C}$ fail to ripen normally and may develop internal discoloration, indicative of chilling injury (CI). To determine if loss of antioxidant protection in the fruit tissue during cold storage could be the cause of these problems, the levels of total, reduced, and oxidized glutathione and ascorbate and the key enzymes glutathione reductase (GR) and ascorbate peroxidase (APX) of the ascorbateglutathione cycle were studied in fruit at 4 and $72 \mathrm{~h}$ after harvest and after $2,4,6$, and 8 weeks of $4{ }^{\circ} \mathrm{C}$ storage. The total phenolic level was also studied due to its potential antioxidant role, and the activity of polyphenoloxidase (PPO) was assayed, as it may contribute to phenolic oxidation and tissue browning. Fruit ethylene production and respiration rates were in typical climacteric patterns during ripening after harvest and after up to 4 weeks of cold storage, increasing from 4 to $72 \mathrm{~h}$ after removal from cold storage, though maximum ethylene production declined after 2 weeks of cold storage. However, fruit showed higher respiration rates at 4 versus $72 \mathrm{~h}$ of ripening at 6 or 8 weeks of cold storage, opposite to that at earlier storage dates, possible evidence of CI. Ripening after harvest generally resulted in an increase in total and reduced glutathione, reduced ascorbate, and total phenolics. However, levels of total and reduced glutathione, total ascorbate, and total phenolics declined as storage time progressed. Neither GR nor APX exhibited changes during ripening or trends over the cold storage period. PPO activity increased as the storage period lengthened. Thus, the declining ability of these components of the protective antioxidant systems during the prolonged stress of low temperature storage may be one of the major causes of pawpaw CI limiting it to 4 weeks or less of cold storage. An increase in reactive oxygen species with prolonged storage, coupled with the increase in PPO activity, may have led to greater oxidative damage and been a major cause of the loss of ripening potential and the tissue browning that occurs in fruit stored for more than 4 weeks.
\end{abstract}

Pawpaw is becoming a high-value alternative crop in the southeastern United States, but the rapid perishability of the fruit is a significant obstacle to the development of a broader fresh pawpaw market. Low temperature storage can slow pawpaw ripening, as fruit stored at $4{ }^{\circ} \mathrm{C}$ for 4 weeks exhibited minimal loss in quality, although softening continued slowly (Archbold and Pomper, 2003; Galli et al., 2008). However, pawpaw fruit cold stored longer than 4 weeks failed to ripen normally and developed internal discoloration, tissue acidification, and off-flavor aroma (Archbold and Pomper, 2008; Galli et al., 2008; Koslanund, 2003), common symptoms of chilling injury (CI) in many crops (Saltveit and Morris, 1990).

The production of reactive oxygen species (ROS) and/or free radicals is an unavoidable consequence of the electron transport involved in respiratory and photosynthetic pathways that normally occurs in plant tissue (Arora et al., 2002; Toivonen, 2004). However, stress events such as fruit ripening increase the production of ROS in plant tissues, causing tissue damage. Under normal stress conditions, adequate protection against

Received for publication 19 Feb. 2009. Accepted for publication 29 May 2009. This research was funded by USDA-NRI Grant 2001-35503-10775.

${ }^{1}$ Corresponding author. E-mail: darchbol@uky.edu. destructive ROS reactions is provided by cellular antioxidant defense systems, including superoxide dismutase (SOD), catalase (CAT), and the ascorbate-glutathione cycle (Asada, 1994; Noctor and Foyer, 1998). The major components of this cycle include glutathione reductase, ascorbate peroxidase, and antioxidant compounds such as ascorbate and glutathione. The capacity of this cycle to protect tissue is dependent on antioxidant concentration and the activity of the aforementioned enzymes. In general, progressive oxidation and degradation of the ascorbate and glutathione pools with extended and/or severe stresses and injury are linked to senescence and cell death (Noctor and Foyer, 1998; Smirnoff, 1996). Pawpaw pulp has relatively high ascorbic acid content (Peterson et al., 1982), so an important antioxidant role for this pool is possible.

Phenolic compounds may work cooperatively with the ascorbate-glutathione-dependent pathway. Phenolics can scavenge ROS due to their redox properties, which allow them to act as reducing agents, hydrogen donors, oxygen scavengers, and metal chelators (Kahkonen et al., 1999). Maldonado et al. (2002a) reported that lignins and tannin polyphenols accumulated in pawpaw-related cherimoya (Annona cherimola) fruit and played an important role in the cell wall hardening observed in cold-injured fruit. Despite their redox protective 
role, phenolics may be responsible for tissue browning during CI development. Enzymatic browning may be caused by oxidation of phenolic compounds by polyphenoloxidase (Mayer and Harel, 1979). Increased phenylalanine ammonia lyase (PAL) activity may also boost phenolic oxidation because it increases the concentration of PPO substrates (Nguyen et al., 2003), though PPO seems to be the key enzyme in tissue browning of cold-damaged fruit and vegetables (Concellon et al., 2004; Leja et al., 2003; Nguyen et al., 2003). Crude extracts of ripe pawpaw fruit pulp have been reported to display PPO activity (Fang et al., 2007); however, there are no studies examining whether PPO activity changes during cold storage of the fruit.

Loss of ripening capacity and tissue browning of pawpaw have been observed for periods of cold storage exceeding 4 weeks (Archbold and Pomper, 2008; Galli et al., 2008; Koslanund, 2003), but nothing is known about the effect of cold storage on pawpaw antioxidant compound content and/or metabolism. Thus, the goal of this study was to determine the effect of cold storage duration on key components of the ascorbate-glutathione cycle and phenolic content and oxidation.

\section{Materials and Methods}

Fruit HARVEST AND COLD STORAGE. In 2004 and 2005, fruit that were just starting to ripen, as indicated by touch to determine if they were slightly soft, were harvested from the cultivars Middletown, PA Golden, Taylor, Taytwo, Shenandoah, Wells, and Wilson; and advanced selections from the PawPaw Foundation breeding program, ' $8-20$ ' and ' $9-58$ '. In addition, unripe fruit were collected from 'Taytwo' 1 week before normal harvest in 2005. On each harvest date, pawpaw fruit were placed in $4{ }^{\circ} \mathrm{C}$ storage for $0,2,4,6$, or 8 weeks. Upon harvest or removal from cold storage, fruit were moved to ambient temperature $\left(21 \pm 2{ }^{\circ} \mathrm{C}\right)$. Fruit weight, firmness, respiration rate, and ethylene production were measured on five randomly selected fruit at 4 and $72 \mathrm{~h}$ after harvest or removal from cold storage. Preliminary work indicated fruit pulp had reached ambient temperature by $3 \mathrm{~h}$ after removal from cold storage. After these measurements in 2005, 'Taytwo' fruit were peeled, sectioned by transverse cuts into $\approx 1$-cm-thick pieces followed by seed removal and then halving each piece, and freezing the tissue in $-80{ }^{\circ} \mathrm{C}$ storage. For each storage and ripening period, there were five fruit per cultivar each year.

RESPIRATION AND ETHYLENE PRODUCTION. Rates of respiratory $\mathrm{CO}_{2}$ and $\mathrm{C}_{2} \mathrm{H}_{4}$ production by individual fruit were obtained by analyzing headspace composition of fruit held for $2 \mathrm{~h}$ in enclosed 0.9-L bottles (Archbold and Pomper, 2003), starting at 4 or $72 \mathrm{~h}$ after harvest or removal from cold storage.

Firmness. The external firmness of each fruit was measured with peel intact after respiration and ethylene production measurements by compression with a Chatillon force gauge (model DFM 10; John Chatillon and Sons, Greensboro, NC) (Archbold and Pomper, 2003).

GLUTATHIONE AND ASCORBIC ACID EXTRACTION AND ASSAY. Frozen tissue $(0.5 \mathrm{~g})$ was homogenized in $2.5 \mathrm{~mL}$ of $5 \%(\mathrm{w} / \mathrm{v})$ metaphosphoric acid, filtered through four layers of Miracloth (Calbiochem, San Diego), and centrifuged at 20,000 $g_{n}$ for 15 min at $4{ }^{\circ} \mathrm{C}$. The supernatant was collected and used for glutathione and ascorbic acid determination. Components of the glutathione pool were assayed according to Griffiths (1980). Total glutathione was measured in a $1.2-\mathrm{mL}$ mixture containing
$400 \mu \mathrm{L}$ of reagent I $\left[110 \mathrm{~mm} \mathrm{Na}_{2} \mathrm{HPO}_{4} \cdot 7 \mathrm{H}_{2} \mathrm{O}, 40 \mathrm{~mm}\right.$ $\mathrm{NaH}_{2} \mathrm{PO}_{4} \cdot \mathrm{H}_{2} \mathrm{O}, 15 \mathrm{~mm}$ EDTA, $0.3 \mathrm{~mm}$ 5-5-dithio-bis(2-nitrobenzoic acid) (DTNB), and $0.04 \% \mathrm{BSA}$ ], $320 \mu \mathrm{L}$ of reagent II [1 mm EDTA, 50 mm imidazole, 0.02\% BSA, 1.5 unit $/ \mathrm{mL}$ GR (baker's yeast, Type III; Sigma, St. Louis)], and $400 \mu \mathrm{L}$ of a 1:10 dilution of extract in $5 \% \mathrm{Na}_{2} \mathrm{HPO}_{4}(\mathrm{pH} 7.5)$. The reaction was initiated with $80 \mu \mathrm{L}$ of $3 \mathrm{~mm}$ NADPH. The change in absorbance at $412 \mathrm{~nm}$ was recorded. Oxidized glutathione (GSSG) was determined by first incubating the mixture with $1 \mathrm{~mL}$ of the 1:10 dilution extract and $40 \mu \mathrm{L}$ of 2-vinylpyridine for $60 \mathrm{~min}$ at $25^{\circ} \mathrm{C}$. Standard curves were prepared by using glutathione and GSSG. Reduced glutathione (GSH) was obtained as the difference between total glutathione and GSSG.

Components of the ascorbate pool were measured according to Foyer et al. (1983) with some modification. To determine total ascorbate, $0.2 \mathrm{~mL}$ of the pawpaw extract was initially reacted with $100 \mu \mathrm{L}$ of $10 \mathrm{~mm}$ dithiothreitol (DTT), which converted dehydroascorbate (DHA) into the reduced form ascorbic acid (AA). The mixture was incubated for $10 \mathrm{~min}$ at room temperature, and then $500 \mu \mathrm{L}$ of $150 \mathrm{~mm}$ phosphate buffer $(\mathrm{pH} 7.4)$ containing $5 \mathrm{~mm}$ EDTA and $100 \mu \mathrm{L}$ of $0.5 \mathrm{M}$ N-ethylmaleimide (NEM) was added. After adding $400 \mu \mathrm{L}$ of $10 \%(\mathrm{w} / \mathrm{v}) \mathrm{TCA}, 400 \mu \mathrm{L}$ of $44 \%(\mathrm{v} / \mathrm{v})$ orthophosphoric acid, $400 \mu \mathrm{L}(\mathrm{w} / \mathrm{v})$ of $2,2^{\prime}$-dipyridyl in $70 \%$ ethanol, and $200 \mu \mathrm{L}$ of $3 \%(\mathrm{w} / \mathrm{v}) \mathrm{FeCl}_{3}$, the mixture was incubated at $37^{\circ} \mathrm{C}$ for $60 \mathrm{~min}$ and the absorbance at $525 \mathrm{~nm}$ was read. AA concentration was measured using the same methodology, but DTT and NEM were replaced with $0.2 \mathrm{~mL}$ of $\mathrm{H}_{2} \mathrm{O}$. A standard curve was produced with AA. DHA level was calculated as the difference between total ascorbate and AA.

GR AND APX extraction AND assay. Frozen tissue $(0.5 \mathrm{~g})$ was homogenized in $5 \mathrm{~mL}$ of $50 \mathrm{~mm}$ Tris- $\mathrm{HCl}(\mathrm{pH} 7.0)$ containing $20 \%(\mathrm{w} / \mathrm{v})$ glycerol, $1 \mathrm{~mm} \mathrm{GSH}$, and $5 \mathrm{~mm} \mathrm{MgCl}_{2}$. The mixture was filtered through four layers of Miracloth and was centrifuged at $25,000 g_{n}$ for $15 \mathrm{~min}$ at $4{ }^{\circ} \mathrm{C}$. The supernatant was used for enzyme activity determination.

GR activity was assayed by following the change in absorbance at $340 \mathrm{~nm}$ according to Foyer and Halliwell (1976) in $50 \mathrm{~mm}$ Tris- $\mathrm{HCl}$ buffer (pH 7.5) containing $5 \mathrm{~mm}$ $\mathrm{MgCl}_{2}, 0.5 \mathrm{~mm} \mathrm{GSSH}, 0.2 \mathrm{~mm} \mathrm{NADPH}$, and extract in a final volume of $1 \mathrm{~mL}$. One unit of GR was defined as the amount of enzyme that used $1 \mu \mathrm{mol} \cdot \mathrm{min}^{-1} \mathrm{NADPH}$ per milligram of protein under the assay conditions. Protein was determined by the method of Bradford (1976) with bovine serum albumin as a standard.

APX activity was assayed by monitoring the change at 290 $\mathrm{nm}$ according to the method of Nakano and Asada (1987). The reaction mixture contained $50 \mathrm{~mm}$ potassium phosphate $(\mathrm{pH}$ 7.0), $1 \mathrm{~mm} \mathrm{AA,} 2.5 \mathrm{mM} \mathrm{H}_{2} \mathrm{O}_{2}$, and extract in a final volume of $1 \mathrm{~mL}$. One unit of APX was defined as the amount of enzyme that oxidized $1 \mu \mathrm{mol} \cdot \mathrm{min}^{-1} \mathrm{AA}$ per milligram of protein under the assay conditions. Protein was determined as above.

Total Phenolic content. Frozen tissue ( $3 \mathrm{~g}$ ) was combined with $4 \mathrm{~mL}$ of $80 \%$ methanol and was homogenized in a Polytron homogenizer (Kinematica, Bohemia, NY). The homogenate was filtered through two layers of cheesecloth and was centrifuged at $1500 g_{\mathrm{n}}$ for 5 to $6 \mathrm{~min}$. A portion of supernatant was diluted with deionized water to achieve a $5 \%$ methanol concentration for analysis. Total phenolic content was measured using a modified version of the Glories' method as described by Fukomoto and Mazza (2000). For this assay, $500 \mu \mathrm{L}$ of $5 \%$ methanol pawpaw extract was combined with $240 \mu \mathrm{L}$ of $0.1 \%$ 
$\mathrm{HCl}$ in $95 \%$ ethanol and $4.31 \mathrm{~mL}$ of $2 \%$ ethanol. The solution was vortexed and the absorbance was read at $280 \mathrm{~nm}$ against a blank containing 5\% methanol. Results were derived from a chlorogenic acid standard curve and are expressed as milligrams of chlorogenic acid per 100 grams of fresh weight.

PPO, PAL, AND POD enZyme EXtraction AND ASSAY. For PPO, peroxidase (POD), and PAL extraction and assay, $3 \mathrm{~g}$ of frozen tissue was homogenized in $9 \mathrm{~mL}$ of $100 \mathrm{~mm}$ phosphate buffer (pH 6.2) containing $2 \mathrm{~g}$ of PVPP (Dogan et al., 2005). The supernatant from the homogenate was filtered through four layers of cheesecloth and Miracloth and was centrifuged at $14,000 g_{\mathrm{n}}$ for $15 \mathrm{~min}$ at $4{ }^{\circ} \mathrm{C}$. The supernatant was collected as crude enzyme and was used for enzyme activity assay. PPO activity was determined in a $1-\mathrm{mL}$ reaction mixture containing $150 \mu \mathrm{L}$ of $10 \mathrm{~mm}$ catechol, $550 \mu \mathrm{L}$ of phosphate extraction buffer, and $300 \mu \mathrm{L}$ of crude extract. Catechol oxidation was followed over time at $420 \mathrm{~nm}$, and PPO activity was expressed as $\Delta A_{420}$ per minute per milligrams of protein. PAL activity was determined in a $1-\mathrm{mL}$ reaction mixture containing $10 \mu \mathrm{L}$ of 10 mM L-phenylalanine, $570 \mu \mathrm{L}$ of $30 \mathrm{~mm}$ Tris buffer ( $\mathrm{pH} 8.4)$, and $330 \mu \mathrm{L}$ of crude extract (Maldonado et al., 2002b). Production of cinnamate was followed over time at $290 \mathrm{~nm}$, and PAL activity was expressed as $\Delta A_{290}$ per minute per milligram of protein. POD activity was determined in a $1-\mathrm{mL}$ reaction mixture containing $170 \mu \mathrm{L}$ of $0.03 \%(\mathrm{v} / \mathrm{v}) \mathrm{H}_{2} \mathrm{O}_{2}, 333 \mu \mathrm{L}$ of $40 \mathrm{~mm}$ guaiacol, $333 \mu \mathrm{L}$ of Tris buffer ( $\mathrm{pH} 5.6)$, and $164 \mu \mathrm{L}$ of crude extract (Flurkey and Jen, 1978). Guaiacol oxidation was followed over time at $470 \mathrm{~nm}$, and POD activity was expressed as $\Delta A_{470}$ per minute per milligram of protein. Protein was determined as above.

Statistical analysis. All data were subjected to analysis of variance. Single df contrasts were used to compare 4- versus 72-h values and determine if there were linear or quadratic trends across storage periods. Means were compared by Fisher's protected least significance difference (LSD) at $P=0.05$ using SAS (version 9.1; SAS Institute, Cary, NC).

\section{Results and Discussion}

ETHYLENE PRODUCTION, RESPIRATION, AND FRUIT FIRMNESS. There were no differences in ethylene production, respiration rate, or firmness among genotypes (data not shown), therefore only values for main effects of storage time and 4 versus $72 \mathrm{~h}$ of ripening are presented. Ethylene production was highest after 2 weeks of cold storage and $72 \mathrm{~h}$ of ripening, declining as storage period continued (Fig. 1A). The rate of production increased from 4 to $72 \mathrm{~h}$ across storage dates $(P>0.05)$. Prior studies have reported higher levels of ethylene production after 4 rather than 2 weeks of cold storage (Archbold and Pomper, 2003; Archbold et al., 2003; Galli et al., 2008), but the reasons for the earlier peak in the present work are not clear.

The respiration rate was high after harvest, but only increased $(P>0.05)$ between 4 and $72 \mathrm{~h}$ of ripening after 2 and 4 weeks of cold storage (Fig. 1B). After 6 weeks of cold storage, the respiration rate was higher immediately after removal from cold storage compared with $72 \mathrm{~h}$ later, possible evidence of CI with extended storage as previously described (Archbold and Pomper, 2008; Galli et al., 2008). 'Taytwo' exhibited trends in ethylene production and respiration similar, though not identical, to the pooled genotypes (Fig. 1, A and B), and was thus selected as representative of the genotypes for subsequent biochemical analyses due to its greater abundance.
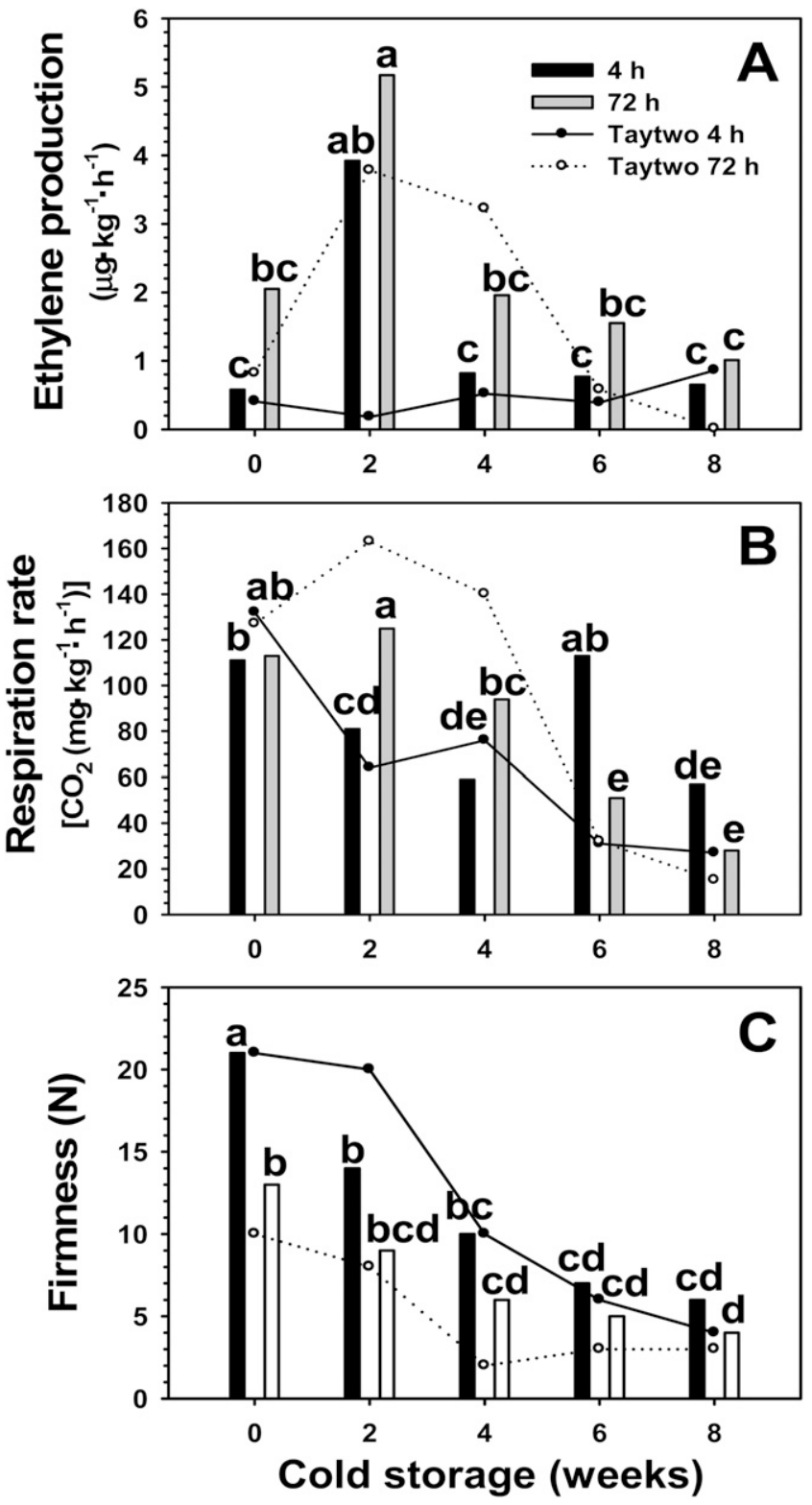

Fig. 1. Pawpaw fruit ethylene production $(\mathbf{A})$, respiration rate $(\mathbf{B})$, and firmness (C) of nine cultivars in 2004 and 2005 measured 4 and $72 \mathrm{~h}$ after harvest or after $2,4,6,8$, or 12 weeks of $4{ }^{\circ} \mathrm{C}$ storage. Values of the vertical bars are means of 10 fruit (five each year for each storage and ripening period) per cultivar. Letters above individual vertical bars indicate means are significantly different by Fisher's LSD at $P=0.05$. 'Taytwo' mean values on each date are represented by individual data points.

After harvest, fruit exhibited a rapid decline in firmness at ambient temperature (Fig. 1C). Firmness of all cultivars also declined during cold storage as has been previously reported (Archbold and Pomper, 2003; Galli et al., 2008). A positive correlation between cold storage length and loss of firmness has been observed in peach (Prunus persica) (Forlani et al., 2004) and cherimoya (Alique et al., 1994) as well. Due to this loss during cold storage, pawpaw fruit firmness was already low and did not decline further from 4 to $72 \mathrm{~h}$ after removal from cold storage.

Several symptoms of CI may occur with ripening fruit that can be distinguished from senescence (Saltveit and Morris, 1990). Pawpaw stored at $4{ }^{\circ} \mathrm{C}$ for more than 4 weeks then moved 
to $21^{\circ} \mathrm{C}$ for ripening exhibited symptoms that were not observed with overripe fruit after harvest, including higher respiration rates at 4 versus $72 \mathrm{~h}$ of ripening, a decline in the production of signature volatile ester compounds and an increase in off-flavor compounds (Galli et al., 2008), and the occurrence of fruit pulp browning (Archbold and Pomper, 2008).

AsCorbate-GLUTATHIONE PATHWAY AT HARVEST AND DURING COLD STORAGE. In both unripe and ripe fruit, GSH represented over $95 \%$ of the total glutathione pool in pawpaw (Table 1). Across storage times, total glutathione and GSH were generally higher in fruit ripened for 72 versus $4 \mathrm{~h}$, with the highest values at harvest and declining at longer storage periods. In contrast, few differences were observed in GSSG concentration before or after cold storage and ripening. The highest GSSG concentration was in fruit cold stored for 2 weeks and the lowest concentrations were measured in fruit cold stored for 2 weeks and ripened for $72 \mathrm{~h}$. The GSH/GSSG values were higher through 4 weeks of cold storage than at later times. The decline in total and reduced glutathione and the GSH/GSSG ratio after 6 or 8 weeks of cold storage could contribute to low oxidative stress tolerance. Low GSH concentration and GSH/GSSG values have been related to the failure of the antioxidant protection system that can occur after prolonged stress (Mondal et al., 2004; Wang et al., 2006).

GR activity exhibited its maximum value in pawpaw fruit cold stored for 6 weeks and ripened for $72 \mathrm{~h}$ (Table 1). However, no trends over ripening or storage time were observed. An increase in GR activity in tissues exposed to low temperature stress has been related to an increase in GSH concentration and a general protection against oxidative stress (Ding et al., 2007; Fuller et al., 1998; Malacrida et al., 2007). The lack of GR upregulation in cold-stored pawpaw fruit may explain the decline of GSH and the GSH/GSSG ratio observed during cold storage.

The total ascorbate content of 'Taytwo' fruit was highest at harvest (Table 2), similar to the value reported by Peterson et al. (1982). By 2 weeks of cold storage, total ascorbate had dropped, and there were declining trends over storage time when measured at 4 or $72 \mathrm{~h}$. However, ripening had no effect on total ascorbate. At harvest, $41 \%$ of the total ascorbate pool was
AA and 59\% was DHA. However, after 2, 6, and 8 weeks of cold storage followed by $72 \mathrm{~h}$ of ripening, AA comprised over $90 \%$ of the total pool with only a negligible amount of DHA present (Table 2). No trends in AA concentration across cold storage periods were observed, though values increased from 4 to $72 \mathrm{~h}$ of ripening. DHA values declined at 4 or $72 \mathrm{~h}$ across cold storage periods, and ripening did not affect DHA or AA/DHA values.

APX activity did not change during fruit ripening nor exhibit a clear trend during cold storage, though it reached a maximum value after 2 weeks of cold storage and very low values at 4 weeks and beyond (Table 2). Low APX activity would limit DHA production and impair the $\mathrm{H}_{2} \mathrm{O}_{2}$ scavenging system with resulting accumulation of $\mathrm{H}_{2} \mathrm{O}_{2}$ (Zhang and Kirkham, 1996), and lead to oxidative stress damage and increased postharvest senescence (Barreiro et al., 2001; Mondal et al., 2006).

Overall, the GSH/GSSG and AA/DHA ratios did not change, total ascorbate and glutathione declined, and GR or APX activities showed no clear patterns of response to cold storage. These indicate that the ascorbate-glutathione cycle in pawpaw did not contribute to antioxidant protection at extended periods of cold storage.

Phenolic content and PPO activity at harvest and DURING COLD STORAGE. At $72 \mathrm{~h}$ after harvest, the phenolic content of 'Taytwo' pawpaw fruit was $50 \pm 1 \mathrm{mg}$ CA per $100 \mathrm{~g}$ FW (Table 3), similar to that reported by Kobayashi et al. (2008). There was a quadratic trend in phenolic content across storage date at 4 and at $72 \mathrm{~h}$ with maximum values from 2 to 6 weeks of cold storage (Table 3 ). Ripening generally resulted in an increase in phenolic content. Accumulation of phenolic compounds in pawpaw fruit may be an acclimatizing response to cold storage as observed with other species (Lattanzio et al., 2001; Nguyen et al., 2003). Loss of phenolic compounds in pawpaw at longer periods of cold storage may expose the tissue to increased CI.

Three enzymes play a major role in phenolic compound oxidation and consequent tissue browning: PAL, PPO, and POD. After 4 weeks of cold storage, enzyme activities were: $\mathrm{PAL}$ at $0.004 \pm 0.003 \Delta A_{290}$ per minute per milligram of protein; POD at $0.08 \pm 0.02 \Delta A_{420}$ per minute per milligram of

Table 1. Total glutathione, oxidized glutathione (GSSG), and reduced glutathione (GSH) content and glutathione reductase (GR) activity in

'Taytwo' pawpaw fruit 1 week before commercial harvest (unripe), at harvest, and after $2,4,6$, and 8 weeks of $4{ }^{\circ} \mathrm{C}$ storage (CS).

Measurements were collected after 4 and $72 \mathrm{~h}$ of ripening. Data are the mean $\pm \mathrm{SE}$ of $\mathrm{n}=3$ replications. Probability values of single-df contrasts for 4 versus $72 \mathrm{~h}$ and linear (L) and quadratic (Q) trends across storage dates at 4 or $72 \mathrm{~h}$ are presented.

\begin{tabular}{|c|c|c|c|c|c|c|c|c|c|c|}
\hline \multirow[b]{3}{*}{ Sampling time } & & & \multicolumn{6}{|c|}{ Glutathione pools $\left(\mathrm{nmol} \cdot \mathrm{g}^{-1} \mathrm{FW}\right)$} & \multirow{2}{*}{\multicolumn{2}{|c|}{$\begin{array}{c}\text { GR activity [NADPH } \\
\left(\mu \mathrm{mol} \cdot \mathrm{min}^{-1} \cdot \mathrm{mg}^{-1} \text { protein }\right)\end{array}$}} \\
\hline & \multicolumn{2}{|c|}{ Total } & \multicolumn{2}{|c|}{ GSSG } & \multicolumn{2}{|c|}{ GSH } & \multicolumn{2}{|c|}{ GSH/GSSG } & & \\
\hline & $4 \mathrm{~h}$ & $72 \mathrm{~h}$ & $4 \mathrm{~h}$ & $72 \mathrm{~h}$ & $4 \mathrm{~h}$ & $72 \mathrm{~h}$ & $4 \mathrm{~h}$ & $72 \mathrm{~h}$ & $4 \mathrm{~h}$ & $72 \mathrm{~h}$ \\
\hline Unripe & \multicolumn{2}{|c|}{$56 \pm 12$} & \multicolumn{2}{|c|}{$2.0 \pm 0.2$} & \multicolumn{2}{|c|}{$54 \pm 12$} & \multicolumn{2}{|c|}{$27 \pm 4$} & \multicolumn{2}{|c|}{$1.4 \pm 0.3$} \\
\hline $2 \mathrm{CS}$ & $48 \pm 14$ & $71 \pm 3$ & $2.7 \pm 0.8$ & $1.5 \pm 0.1$ & $45 \pm 14$ & $70 \pm 3$ & $17 \pm 10$ & $46 \pm 2$ & $1.3 \pm 0.9$ & $0.1 \pm 0.1$ \\
\hline $4 \mathrm{CS}$ & $46 \pm 23$ & $95 \pm 10$ & $1.7 \pm 0.1$ & $2.1 \pm 0.4$ & $44 \pm 23$ & $93 \pm 10$ & $26 \pm 12$ & $45 \pm 15$ & $0.1 \pm 0.6$ & $0.5 \pm 0.3$ \\
\hline $6 \mathrm{CS}$ & $11 \pm 2$ & $56 \pm 12$ & $1.8 \pm 0.3$ & $1.6 \pm 0.1$ & $9 \pm 2$ & $54 \pm 12$ & $5 \pm 2$ & $33 \pm 9$ & $1.7 \pm 0.6$ & $6.3 \pm 0.3$ \\
\hline $8 \mathrm{CS}$ & \multicolumn{10}{|c|}{ Single-df contrasts $(P)$} \\
\hline 4 vs. $72 \mathrm{~h}$ & \multicolumn{2}{|c|}{0.0018} & \multicolumn{2}{|c|}{0.8344} & \multicolumn{2}{|c|}{0.0014} & \multicolumn{2}{|c|}{0.1398} & \multicolumn{2}{|c|}{0.3831} \\
\hline $4 \mathrm{~h} \mathrm{~L}$ & \multicolumn{2}{|c|}{0.0429} & \multicolumn{2}{|c|}{0.8815} & \multicolumn{2}{|c|}{0.0542} & \multicolumn{2}{|c|}{0.0613} & \multicolumn{2}{|c|}{0.9338} \\
\hline $4 \mathrm{~h} Q$ & \multicolumn{2}{|c|}{0.5324} & \multicolumn{2}{|c|}{0.2224} & \multicolumn{2}{|c|}{0.0940} & \multicolumn{2}{|c|}{0.0299} & \multicolumn{2}{|c|}{0.9499} \\
\hline $72 \mathrm{~h} \mathrm{~L}$ & \multicolumn{2}{|c|}{0.0003} & \multicolumn{2}{|c|}{0.9209} & \multicolumn{2}{|c|}{0.0005} & \multicolumn{2}{|c|}{0.0025} & \multicolumn{2}{|c|}{0.9088} \\
\hline
\end{tabular}


Table 2. Total, reduced (AA), and oxidized (DHA) ascorbate content as ascorbic acid equivalents (AAE) and ascorbate peroxidase (APX) activity in 'Taytwo' pawpaw fruit 1 week before commercial harvest (unripe), at harvest, and after 2, 4, 6, and 8 weeks of $4{ }^{\circ} \mathrm{C}$ storage (CS). Measurements were collected after 4 and $72 \mathrm{~h}$ of ripening. Data are the mean $\pm \mathrm{SE}$ of $\mathrm{n}=3$ replications. Probability values of single-df contrasts for 4 versus $72 \mathrm{~h}$ and linear (L) and quadratic (Q) trends across storage dates at 4 or $72 \mathrm{~h}$ are presented.

\begin{tabular}{|c|c|c|c|c|c|c|c|c|c|c|}
\hline \multirow[b]{3}{*}{ Sampling time } & \multicolumn{8}{|c|}{ Ascorbic acid pools $[\mathrm{AAE}(\mu \mathrm{M} / 100 \mathrm{~g} \mathrm{FW})]$} & \multirow{2}{*}{\multicolumn{2}{|c|}{$\begin{array}{c}\text { APX activity [AA } \\
\left.\left(100 \mu \mathrm{mol} \cdot \mathrm{min}^{-1} \cdot \mathrm{mg}^{-1} \text { protein }\right)\right]\end{array}$}} \\
\hline & \multicolumn{2}{|c|}{ Total } & \multicolumn{2}{|c|}{$\mathrm{AA}$} & \multicolumn{2}{|c|}{ DHA } & \multicolumn{2}{|c|}{ AA/DHA } & & \\
\hline & $4 \mathrm{~h}$ & $72 \mathrm{~h}$ & $4 \mathrm{~h}$ & $72 \mathrm{~h}$ & $4 \mathrm{~h}$ & $72 \mathrm{~h}$ & $4 \mathrm{~h}$ & $72 \mathrm{~h}$ & $4 \mathrm{~h}$ & $72 \mathrm{~h}$ \\
\hline Unripe & \multicolumn{2}{|c|}{$57 \pm 8$} & \multicolumn{2}{|c|}{$25 \pm 4$} & \multicolumn{2}{|c|}{$32 \pm 5$} & \multicolumn{2}{|c|}{$1 \pm 1$} & \multicolumn{2}{|c|}{$23 \pm 8$} \\
\hline $0 \mathrm{CS}$ & $61 \pm 4$ & $72 \pm 5$ & $25 \pm 3$ & $41 \pm 10$ & $36 \pm 3$ & $31 \pm 12$ & $1 \pm 1$ & $1 \pm 1$ & $34 \pm 9$ & $36 \pm 12$ \\
\hline $2 \mathrm{CS}$ & $39 \pm 6$ & $27 \pm 3$ & $20 \pm 4$ & $30 \pm 3$ & $19 \pm 6$ & $1 \pm 1$ & $1 \pm 1$ & $30 \pm 5$ & $303 \pm 203$ & $197 \pm 46$ \\
\hline $4 \mathrm{CS}$ & $35 \pm 7$ & $40 \pm 9$ & $27 \pm 1$ & $38 \pm 5$ & $9 \pm 8$ & $5 \pm 3$ & $3 \pm 1$ & $8 \pm 3$ & $50 \pm 40$ & $10 \pm 3$ \\
\hline $6 \mathrm{CS}$ & $25 \pm 3$ & $33 \pm 7$ & $22 \pm 3$ & $37 \pm 2$ & $3 \pm 2$ & $4 \pm 4$ & $7 \pm 2$ & $9 \pm 2$ & $0 \pm 0$ & $18 \pm 10$ \\
\hline \multirow[t]{2}{*}{$8 \mathrm{CS}$} & $27 \pm 10$ & $35 \pm 9$ & $16 \pm 3$ & $35 \pm 2$ & $14 \pm 10$ & $1 \pm 1$ & $1 \pm 1$ & $35 \pm 3$ & $0 \pm 0$ & $0 \pm 0$ \\
\hline & \multicolumn{10}{|c|}{ Single-df contrasts $(P)$} \\
\hline 4 vs. $72 \mathrm{~h}$ & \multicolumn{2}{|c|}{0.6861} & \multicolumn{2}{|c|}{$<0.0001$} & \multicolumn{2}{|c|}{0.9161} & \multicolumn{2}{|c|}{0.3590} & \multicolumn{2}{|c|}{0.6038} \\
\hline $4 \mathrm{~h} \mathrm{~L}$ & \multicolumn{2}{|c|}{0.0012} & \multicolumn{2}{|c|}{0.2306} & \multicolumn{2}{|c|}{$<0.0001$} & \multicolumn{2}{|c|}{0.6569} & \multicolumn{2}{|c|}{0.0793} \\
\hline $4 \mathrm{~h} \mathrm{Q}$ & \multicolumn{2}{|c|}{0.1074} & \multicolumn{2}{|c|}{0.4123} & \multicolumn{2}{|c|}{0.0745} & \multicolumn{2}{|c|}{0.5987} & \multicolumn{2}{|c|}{0.1946} \\
\hline $72 \mathrm{~h} \mathrm{~L}$ & \multicolumn{2}{|c|}{0.0006} & \multicolumn{2}{|c|}{0.7821} & \multicolumn{2}{|c|}{0.0147} & \multicolumn{2}{|c|}{0.2464} & \multicolumn{2}{|c|}{0.2293} \\
\hline $72 \mathrm{~h} \mathrm{Q}$ & \multicolumn{2}{|c|}{0.0478} & \multicolumn{2}{|c|}{0.6075} & 0.0 & & & & & \\
\hline
\end{tabular}

Table 3. Total phenolic content [as chlorogenic acid (CA)] and polyphenoloxidase (PPO) activity of 'Taytwo' pawpaw fruit during cold storage. PPO activity was measured 1 week before commercial harvest (unripe), at harvest, and after $2,4,6$, and 8 weeks of $4{ }^{\circ} \mathrm{C}$ storage (CS). Measurements were taken after 4 and $72 \mathrm{~h}$ of ripening. Data are the mean $\pm \mathrm{SE}$ of $\mathrm{n}=3$ replications. Probability values of single-df contrasts for 4 versus $72 \mathrm{~h}$ and linear (L) and quadratic (Q) trends across storage dates at 4 or $72 \mathrm{~h}$ are presented.

\begin{tabular}{|c|c|c|c|c|}
\hline \multirow[b]{2}{*}{ Sampling time } & \multicolumn{2}{|c|}{ Phenolic content [CA $(\mathrm{mg} / 100 \mathrm{~g} \mathrm{FW})]$} & \multicolumn{2}{|c|}{ PPO activity $\left(\Delta A_{420}\right.$ per min per $\mathrm{mg}$ protein $)$} \\
\hline & $4 \mathrm{~h}$ & $72 \mathrm{~h}$ & $4 \mathrm{~h}$ & $72 \mathrm{~h}$ \\
\hline Unripe & \multicolumn{2}{|c|}{$115 \pm 16$} & \multicolumn{2}{|c|}{$0.10 \pm 0.03$} \\
\hline $0 \mathrm{CS}$ & $5 \pm 4$ & $50 \pm 7$ & $0.11 \pm 0.08$ & $0.17 \pm 0.02$ \\
\hline $4 \mathrm{CS}$ & $66 \pm 10$ & $80 \pm 5$ & $0.10 \pm 0.04$ & $0.25 \pm 0.05$ \\
\hline $6 \mathrm{CS}$ & $29 \pm 10$ & $113 \pm 20$ & $0.17 \pm 0.09$ & $0.18 \pm 0.06$ \\
\hline $8 \mathrm{CS}$ & $7 \pm 5$ & $20 \pm 7$ & $0.33 \pm 0.05$ & $0.29 \pm 0.06$ \\
\hline 4 vs. $72 \mathrm{~h}$ & & & & \\
\hline $4 \mathrm{~h} \mathrm{~L}$ & & & & \\
\hline $4 \mathrm{~h} \mathrm{Q}$ & & & & \\
\hline $72 \mathrm{~h} \mathrm{~L}$ & & & & \\
\hline $72 \mathrm{~h} \mathrm{Q}$ & & & & \\
\hline
\end{tabular}

protein; and PPO at $0.35 \pm 0.04 \Delta A_{470}$ per minute per milligram of protein. However, only PPO activity increased between 4 and 8 weeks of cold storage (data not shown). Thus, PPO was the focus of subsequent work.

Over storage time, PPO activity increased linearly at $4 \mathrm{~h}$ but not $72 \mathrm{~h}$ (Table 3). Storage period has had a similar effect on other species (Dogan et al., 2005; Gooding et al., 2001; Nguyen et al., 2003). The highest PPO activity was found at 8 weeks of cold storage and $4 \mathrm{~h}$. No correlation was found between PPO activity and total phenolic concentration $(\mathrm{r}=0.49, P>0.05)$, perhaps because PPO and substrate are in separate cellular compartments and/or PPO substrate and product are part of the total polyphenol pool measured by the assay used in this work. Interestingly, at 8 weeks, PPO activity reached its maximum value when total phenolics, glutathione, and ascorbate reached their minimums in pawpaw. The loss of antioxidant protection in overstored pawpaw could allow the increase in PPO activity to cause browning of pawpaw pulp (Archbold and Pomper,
2008) as membrane deterioration and leakage increased phenolic substrate levels.

Because PPO activity at $72 \mathrm{~h}$ did not change with cold storage duration, but total phenolic concentration declined, other metabolic events such as Maillard reactions may be involved in browning and/or the phenolic compounds responsible for discoloration may be produced by $o$-quinone polymerization (Dogan et al., 2005). Nonetheless, the oxidation of $o$-diphenols to $o$-quinones catalyzed by PPO may be important contributors to pawpaw tissue browning, as noted in other species during senescence or CI (Dogan et al., 2005; Gooding et al., 2001; Nguyen et al., 2003).

Through 4 weeks of cold storage, phenolic content increased while components of the ascorbate-glutathione cycle were similar to the values at harvest, suggesting the fruit were protected from oxidative damage. However, beyond 4 weeks of cold storage, these declined while APX and GR activities showed no change. These events could result in increasing low 
temperature-mediated oxidative stress damage and impaired ripening (Archbold and Pomper, 2003; Galli et al., 2008; Koslanund, 2003), if activities of other antioxidant enzymes such as SOD and CAT were insufficient to protect the tissue from ROS.

\section{Literature Cited}

Alique, R., J.P. Zamorano, M.L. Calvo, C. Merodio, and J.L. De la Plaza. 1994. Tolerance of cherimoya (Annona cherimola Mill.) to cold storage. J. Amer. Soc. Hort. Sci. 119:524-528.

Archbold, D.D. and K.W. Pomper. 2003. Ripening pawpaw fruit exhibit respiratory and ethylene climacterics. Postharvest Biol. Technol. 30:99-103.

Archbold, D.D., K.W. Pomper, and Pawpaw. 2008. Recommendations for maintaining postharvest quality. 11 May 2009. $<$ http://postharvest. ucdavis.edu/Produce/ProduceFacts/Fruit/pawpaw_graphics.shtml $>$.

Archbold, D.D., R. Koslanund, and K.W. Pomper. 2003. Ripening and postharvest storage of pawpaw. HortTechnology 13:439-441.

Arora, A., R.K. Sairam, and G.C. Srivastava. 2002. Oxidative stress and antioxidative systems in plants. Curr. Sci. 82:1227-1238.

Asada, K. 1994. Production and action of active oxygen species in photosynthetic tissues, p. 77-104. In: C.H. Foyer and P.M. Mullineaux (eds.). Causes of photooxidative stress and amelioration of defense systems in plants. CRC Press, Boca Raton, FL.

Barreiro, M.G., F.C. Lindo, and M. Pinto. 2001. Physicochemical characterization of the postharvest senescence of the winter melon 'Tendra'. Fruits 56:51-58.

Bradford, M.M. 1976. A rapid and sensitive method for the quantitation of microgram quantities of protein utilizing the principles of protein-dye binding. Ann. Biochem. 72:248-254.

Concellon, A., M.C. Anon, and A.R. Chaves. 2004. Characterization and changes in polyphenol oxidase from eggplant fruit (Solanum melongena L.) during storage at low temperature. Food Chem. 88: 17-24.

Ding, Z.-S., S.-P. Tian, X.-L. Zheng, Z.-W. Zhou, and Y. Xu. 2007. Responses of reactive oxygen metabolism and quality in mango fruit to exogenous oxalic acid or salicylic acid under chilling temperature stress. Physiol. Plant. 130:112-121.

Dogan, S., Y. Turan, H. Erturk, and O. Arslan. 2005. Characterization and purification of polyphenol oxidase from artichoke (Cynara scolymus L.). J. Agr. Food Chem. 53:776-785.

Fang, C., Y.L. Xiong, C. Wang, and K.W. Pomper. 2007. Extraction and characterization of polyphenol oxidase in pawpaw (Asimina triloba) fruit. J. Food Biochem. 31:603-620.

Flurkey, W.H. and J.J. Jen. 1978. Peroxidase and polyphenoloxidase activities in developing peaches. J. Food Sci. 43:1826-1828.

Forlani, M., B. Basile, C. Cirillo, and A. Petito. 2004. Evolution of some qualitative parameters of peach fruit during on-tree ripening and post-harvest (Prunus persica (L.) Batsch.). Italus Hortus 11:34-36.

Foyer, C.H. and B. Halliwell. 1976. The presence of glutathione and glutathione reductase in chloroplast: A proposed role in ascorbic acid metabolism. Planta 133:21-25.

Foyer, C.H., J. Rowell, and D. Walker. 1983. Measurements of the ascorbate content of spinach leaf protoplast and chloroplast during illumination. Planta 157:239-244.

Fukomoto, L.R. and G. Mazza. 2000. Assessing antioxidant and prooxidant activities of phenolics. J. Agr. Food Chem. 48:35973604.

Fuller, M., J.J. Hopwood, D.S. Anson, and J.M. Sala. 1998. Involvement of oxidative stress in chilling injury in cold-stored mandarin fruit. Postharvest Biol. Technol. 13:255-261.

Galli, F., D.D. Archbold, and K.W. Pomper. 2008. Loss of ripening capacity of pawpaw fruit with extended cold storage. J. Agr. Food Chem. 56:10683-10688.

Gooding, P.S., C. Bird, and S.P. Robinson. 2001. Molecular cloning and characterization of banana fruit polyphenol oxidase. Planta 213: 748-757.
Griffiths, O.W. 1980. Determination of glutathione and glutathione disulphide using glutathione reductase and 2-vinylpyridine. Ann. Biochem. 106:207-212.

Kahkonen, M.P., A.I. Hopia, H.J. Vuorela, J.P. Rauha, K. Pihlaja, T.S. Kujala, and M. Heinonen. 1999. Antioxidant activity of plant extracts containing phenolic compounds. J. Agr. Food Chem. 47:39543962.

Kobayashi, H., C. Wang, and K.W. Pomper. 2008. Phenolic content and antioxidant capacity of pawpaw fruit (Asimina triloba L.) at different ripening stages. HortScience 43:268-270.

Koslanund, R. 2003. Ethylene production, fruit softening, and their manipulation during pawpaw ripening. University of Kentucky, Lexington, Ph.D. Diss.

Lattanzio, V., D. Di Venere, V. Linsalata, P. Bertolini, A. Hipólito, and M. Salerno. 2001. Low temperature metabolism of apple phenolics and quiescence of Phlyctaena vagabunda. J. Agr. Food Chem. 49:5817-5821.

Leja, M., A. Mareczek, and J. Ben. 2003. Antioxidant properties of two apple cultivars during long term storage. Food Chem. 80:303-307.

Malacrida, C., E.M. Valle, and S.B. Boggio. 2007. Postharvest chilling induces oxidative stress response in the dwarf tomato cultivar MicroTom. Physiol. Plant. 127:10-18.

Maldonado, R., A.D. Molina-Garcia, M.T. Sanchez-Ballestra, M.I. Escribano, and C. Merodio. 2002a. High $\mathrm{CO}_{2}$ atmosphere modulating the phenolic response associated with cell adhesion and hardening of Annona cherimola fruit stored at chilling temperature. J. Agr. Food Chem. 50:7564-7569.

Maldonado, R., M.I. Escribano, and C. Merodio. 2002b. Relationship between the levels of ammonia and coordination of phenylalanine ammonia-lyase and phosphoenolpyruvate carboxylase in Annona cherimola stored under different conditions. Postharvest Biol. Technol. 25:301-309.

Mayer, A.M. and E. Harel. 1979. Polyphenol oxidases in plants. Phytochemistry 18:193-215.

Mondal, K., N.S. Sharma, S.P. Malhotra, D. Kamal, and R.O. Singh. 2006. Oxidative stress and antioxidant systems in tomato fruits stored under normal and hypoxic conditions. Physiol. Mol. Biol. Plants 12:145-150.

Mondal, K., N.S. Sharma, S.P. Malhotra, K. Dhawan, and R. Singh. 2004. Antioxidant systems in ripening tomato fruits. Biol. Plant. 48: 49-53.

Nakano, Y. and K. Asada. 1987. Purification of ascorbate peroxidase in spinach chloroplast: Its inactivation in ascorbate-depleted medium and reactivation by monodehydroascorbate radical. Plant Cell Physiol. 28:131-140.

Nguyen, T.B.T., S. Ketsa, and W.G. van Doorn. 2003. Relationship between browning and the activities of polyphenol oxidase and phenylalanine ammonia lyase in banana peel during low temperature storage. Postharvest Biol. Technol. 30:187-193.

Noctor, G. and C.H. Foyer. 1998. Ascorbate and glutathione: Keeping active oxygen under control. Annu. Rev. Plant Physiol. Plant Mol. Biol. 49:249-279.

Peterson, R.N., J.P. Cherry, and J.G. Simmons. 1982. Composition of pawpaw (Asimina triloba) fruit. Northern Nut Growers Assn. Annu. Rpt. 73:97-107.

Saltveit, M.E., Jr. and L.L. Morris. 1990. Overview of chilling injury of horticultural crops, p. 3-15. In: C.Y. Wang (ed.). Chilling injury of horticultural crops. CRC Press, Boca Raton, FL.

Smirnoff, N. 1996. The function and metabolism of ascorbic acid in plants. Ann. Bot. (Lond.) 78:661-669.

Toivonen, P.M.A. 2004. Postharvest storage procedures and oxidative stress. HortScience 39:928-942.

Wang, L., S. Chen, W. Kong, S. Li, and D.D. Archbold. 2006. Salicylic acid pretreatment alleviates chilling injury and effects the antioxidant system and heat shock proteins of peaches during cold storage. Postharvest Biol. Technol. 41:244-251.

Zhang, J. and M.B. Kirkham. 1996. Antioxidant responses to drought in sunflower and sorghum seedlings. New Phytol. 132:361-373. 